\title{
Research on the Technology Spillover Effect of Taiwanese Investment on Agricultural Products Processing Industry in Mainland China
}

\author{
Chang Lin, Jiangfan Yang \\ College of Economic, Fujian Agriculture and Forestry University \\ China, Fuzhou 350002
}

\begin{abstract}
In order to test the technology spillover effect of Taiwanese investment on the development of agricultural products processing industry in mainland China, this paper is based on the panel data of 10 segments of China's agricultural products processing industry and the panel data from 2007 to 2012. The panel data model is used for the empirical test. The result shows that Taiwanese direct investment has not been able to bring direct technology spillover effect to agricultural products processing industry in mainland China. However, it can improve the overseas openness of agricultural products processing industry in mainland China and reduce the technical gap between the two sides of the mainland. And then it will have indirect technology spillover effect on the agricultural products processing industry in mainland China. The conclusions of this paper provide a new basis to judge whether "Taiwanese investment will help the development of agricultural products processing industry in mainland China and is of important decision-making reference value.
\end{abstract}

Keywords-Agricultural products processing industry; Taiwanese direct investment; Technology spillover effect; Panel data model

\section{INTRODUCTION}

Since the reform and open, the Taiwan enterprises based on technology advantages, management advantages, brand advantages and channel advantages, the advantages of the international management experience and geographical advantages, not using China's low production costs, tax incentives and other advantages, gradually increase investments in mainland China agricultural products processing industry. However, in recent years, Taiwanese businessmen reduced investments in mainland China's agricultural products processing industry. And whether the situation should be paid attention to by all levels of government and relevant departments. It need to solve a real problem: How is the contribution of Taiwanese investment in China's agricultural products processing industry? But the current academic research results failed to give a clear answer. Based on the above background, this paper will base on the mainland China
10 agricultural products processing industry segments, panel data from 2007 - 2012 to measure Taiwanese investment in China's agricultural products processing industry technology spillover effect so that we can answer the above practical problems. It is of important decision-making reference value.

\section{EVOLUTION CHARACTERISTICS OF TAIWANESE INVESTMENT IN AGRICULTURAL PRODUCTS PROCESSING INDUSTRY IN MAINLAND CHINA}

The table 1 shows that first, overall, from 2005 to 2014, Taiwanese investment in China's agricultural products processing industry in 2011 is a watershed, which shows two significant differences in the evolution of characteristics. Investment increased year by year between 2005 and 2011, which increased from \$554 million in 2005 to $\$ 812$ million in 2011. And then it by dropped to $\$ 419$ million in 2014. Second, from the breakdown of the industry, from 2005 to 2014, food manufacturing, textile and pulp, paper and paper products manufacturing industry are the main areas for Taiwan's investment in mainland China's agricultural products processing industry. Among them, the proportion of total investment in food manufacturing investment increased from $8.47 \%$ in 2005 to $32.22 \%$; the total investment in pulp, paper and paper products accounted for a large proportion of the total investment, with a maximum of $29.62 \%$ in 2007 , and it is $15.75 \%$ in 2014 ; the proportion of textile investment in total investment decreased from $26.79 \%$ in 2005 to $15.13 \%$ in 2014 . In addition, Taiwanese investment in tobacco manufacturing in mainland China is zero for the rest of the year, excluding $\$ 13.5$ million in 2010. In addition to changes of investment trends, Taiwanese investment in agricultural products processing industry in mainland China has gradually shifted to large scale and more long-term, which has been initially concentrated in the investment of individual agricultural products, but gradually turned to the agricultural products processing industry as a whole supporting investment [1]. In addition, the investment model is transformed into a sole proprietorship business from the joint venture or cooperation. 
TABLE I. TAIWAN BUSINESSMEN INVESTMENT ON THE MAINLAND SUB-INDUSTRY STATISTICS FROM 2005 TO 2014 (UNIT: MILLION DOLLARS)

\begin{tabular}{|c|c|c|c|c|c|c|c|c|c|c|}
\hline Years & 2005 & 2006 & 2007 & 2008 & 2009 & 2010 & 2011 & 2012 & 2013 & 2014 \\
\hline $\begin{array}{c}\text { Food manufacturing } \\
\text { industry }\end{array}$ & 46.9 & 71.6 & 63.6 & 188.8 & 337.0 & 198.2 & 202.9 & 145.3 & 125.9 & 135.0 \\
\hline $\begin{array}{c}\text { Beverage } \\
\text { manufacturing }\end{array}$ & 6.5 & 28.1 & 8.0 & 51.5 & 28.7 & 9.0 & 63.5 & 76.5 & 118.8 & 46.0 \\
\hline Textile industry & 148.5 & 110.1 & 103.4 & 103.3 & 60.9 & 114.6 & 84.2 & 74.5 & 6.0 & 63.4 \\
\hline $\begin{array}{c}\text { Clothing and apparel } \\
\text { manufacturing } \\
\text { industry }\end{array}$ & 40.4 & 55.2 & 57.4 & 27.5 & 56.4 & 76.4 & 29.2 & 19.8 & 18.8 & 34.2 \\
\hline $\begin{array}{l}\text { Leather, fur and its } \\
\text { products } \\
\text { manufacturing } \\
\text { industry }\end{array}$ & 41.1 & 67.2 & 56.3 & 27.2 & 37.6 & 82.7 & 154.7 & 91.1 & 69.1 & 47.9 \\
\hline $\begin{array}{l}\text { Wood and bamboo } \\
\text { products } \\
\text { manufacturing pulp, } \\
\text { paper and paper } \\
\text { products } \\
\text { manufacturing } \\
\end{array}$ & 10.5 & 10.8 & 3.3 & 21.2 & 47.5 & 9.0 & 1.4 & 0.6 & 16.4 & 5.2 \\
\hline $\begin{array}{l}\text { Wood and bamboo } \\
\text { products } \\
\text { manufacturing pulp, } \\
\text { paper and paper } \\
\text { products } \\
\text { manufacturing } \\
\end{array}$ & 123.1 & 63.5 & 178.8 & 172.9 & 143.2 & 81.9 & 154.4 & 41.0 & 172.9 & 66.0 \\
\hline $\begin{array}{l}\text { Printing and data } \\
\text { storage media } \\
\text { reproduction industry }\end{array}$ & 23.6 & 13.4 & 11.4 & 6.1 & 0.9 & 5.1 & 7.3 & 7.9 & 13.0 & 17.6 \\
\hline $\begin{array}{l}\text { Rubber manufacturing } \\
\text { industry }\end{array}$ & 107.4 & 63.9 & 98.1 & 14.8 & 1.3 & 70.1 & 66.4 & 91.6 & 53.2 & 1.7 \\
\hline $\begin{array}{c}\text { Furniture } \\
\text { manufacturing } \\
\text { industry }\end{array}$ & 4.2 & 10.8 & 21.4 & 9.7 & 13.9 & 23.2 & 46.1 & 11.8 & 16.0 & 0.0 \\
\hline Total & 554.1 & 496.6 & 603.7 & 625.1 & 729.3 & 672.3 & 812.2 & 562.1 & 612.1 & 419.0 \\
\hline
\end{tabular}

\section{ANALYSIS ON THE INTERNAL MECHANISM OF SPILLOVER EFFECTS OF TAIWANESE INVESTMENT}

The technology spillover effect of foreign direct investment refers to the involuntary diffusion of foreign direct investment through technology, which promotes the improvement of technology and productivity of host countries. It is a manifestation of [2] foreign investment on the host country economy, and is also an important factor affecting the technological progress of the host country and the level of productive forces. According to Mac Dougall [3], foreign investment in the host country will not only bring material technology such as new equipment, new craftsmanship and new design, but also bring advanced management methods and experience into the host country and ultimately help the host enterprises to reduce production costs and enhance market competitiveness. This paper will expand the research results of predecessors and further the analysis of the mechanism of foreign direct investment on the technology spillover effect of the host country, mainly through the five intermediary variables such as human capital, trade openness, financial a. Source: According to Taiwan's "Ministry of Economic Affairs" Investment Review Committee market efficiency, market competition degree and technical level gap. They are analyzed as follows:

First, changes in financial market efficiency and trade openness are rising. The growth of these three indicators has led to the inflow of foreign capital in more areas except Taiwan, which has made investment from Taiwan bring more and better technology to promote the spread of technology. It also will lead to more domestic R \& D investment and finally enhance the technology spillover effect [4]. Second, Taiwan businessmen invest in mainland China's related industries, or establish local Taiwan funded enterprises. These measures are undoubtedly crowding out other local enterprises in the mainland and bringing challenges to other enterprises in their local development. Mainland enterprises may introduce advanced production or management technology, thereby enhancing the competitiveness of products in order to compete with Taiwan-funded enterprises [5]. Third, the Taiwanese investment enterprises can bring advanced management experience and management methods so that the Chinese mainland agricultural products processing enterprises improve the internal management and human resources management 
level and personnel training and training mechanism will be more perfect, which are helpful to improve the human capital of agricultural products processing enterprises [6]. Fourth, Taiwanese investment enterprises will bring new equipment, new technology, new design and other material technology to the agricultural products processing industry related industries. And then through the local enterprises "Learning by doing" effect, it can help narrow the technology gap with Taiwanese investment enterprises and even foreign agricultural products processing enterprises, and promote the domestic and international market competitiveness of local firms.

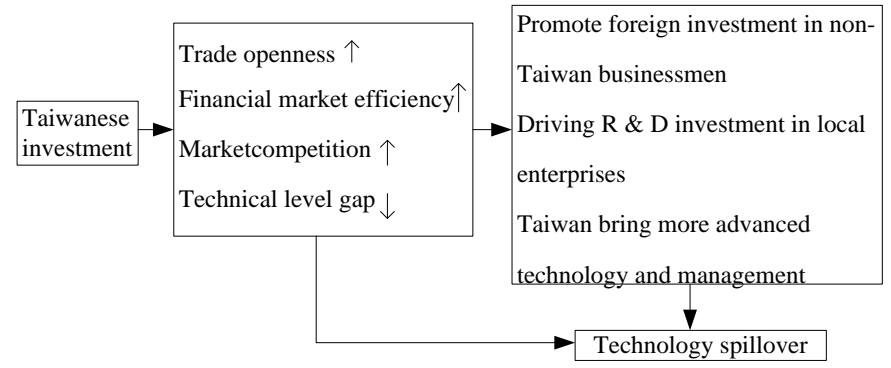

Fig. 1. Technology spillover effect of Taiwanese investment on agricultural products processing industry in mainland China

\section{AN EMPIRICAL ANALYSIS ON THE SPILLOVER EFFECTS OF TAIWANESE INVESTMENT TECHNOLOGY}

\section{A. Model Construction and Variable Selection}

Basing on the theoretical analysis of the technology spillover effects of Taiwanese investment on agricultural products processing enterprises in China, we take into account that this paper will be based on the empirical analysis of 10 agricultural products processing industry. The design of the Taiwanese investment technology spillover effect identification model is Panel data model, as follows:

$$
\begin{aligned}
\operatorname{LnY}_{\mathrm{it}} & =\alpha+\alpha_{1} \operatorname{Lntfdi}_{\mathrm{it}}+\alpha_{2} \operatorname{Lnutfdi}_{\mathrm{it}}+\alpha_{3} \operatorname{Lnlab}_{\mathrm{it}} \\
& +\alpha_{4} \operatorname{Ln}\left(\mathrm{tfdi}_{\mathrm{it}} * \operatorname{hum}_{\mathrm{it}}\right)+\alpha_{5} \operatorname{Ln}\left(\mathrm{tfdi}_{\mathrm{it}} * \text { open }_{\mathrm{it}}\right) \\
& +\alpha_{6} \operatorname{Ln}\left(\mathrm{tfdi}_{\mathrm{it}} * \text { fina }_{\mathrm{it}}\right)+\alpha_{7} \operatorname{Ln}\left(\mathrm{tfdi}_{\mathrm{it}} * \operatorname{gap}_{\mathrm{it}}\right) \\
& +\alpha_{8} \operatorname{Ln}\left(\mathrm{tfdi}_{\mathrm{it}} * \operatorname{comp}_{\mathrm{it}}\right)+\mu_{\mathrm{i}}+v_{\mathrm{t}}+\varepsilon_{\mathrm{it}}
\end{aligned}
$$

Among them, $\mathrm{Y}$ is the dependent variable, which is the measurement variable of the technology spillover effect of the taiwan-business investment on the agricultural products processing enterprises in mainland China: the sales value of the industry of agricultural products processing industry; Open, fina, gap, comp, labor, human, tfdi, utfdi each refer to trade openness and financial market efficiency, technology level gap, the market competition degree, number of labor, human capital, Taiwan direct investment, excluding Taiwan investment in the fixed assets total explanation (see table 2). And tfdi*hum, tfdi*open 、 tfdi*fina 、 tfdi*gap 、 tfdi*comp each stand for Taiwanese investment and human capital, trade openness and financial market efficiency, the technology gap and the degree of competition in the market interaction, which are used to measure the Taiwanese investment indirectly technology spillover effect; I denotes the industry of agricultural products

\begin{tabular}{|c|c|c|c|}
\hline & Symbol & Variable name & Variable interpretation \\
\hline $\begin{array}{l}\text { Dependent } \\
\text { variable }\end{array}$ & Y & \multicolumn{2}{|c|}{ Sales value of agricultural products processing industry and subdivision industry } \\
\hline \multirow{8}{*}{$\begin{array}{c}\text { Independent } \\
\text { variable }\end{array}$} & open & Openness of trade & $\begin{array}{l}\text { The proportion of export value and sales output value of agricultural } \\
\text { products processing industry }\end{array}$ \\
\hline & fina & $\begin{array}{l}\text { Financial market } \\
\text { efficiency }\end{array}$ & $\begin{array}{l}\text { The ratio of current liabilities to total liabilities of industrial enterprises } \\
\text { above designated size }\end{array}$ \\
\hline & gap & Technological gap & $\begin{array}{l}\text { Taiwan's agricultural products processing industry breakdown of labor } \\
\text { productivity (total industrial output divided by the number of } \\
\text { employees) and the ratio of mainland China }\end{array}$ \\
\hline & comp & $\begin{array}{l}\text { Market competition } \\
\text { degree }\end{array}$ & $\begin{array}{l}\text { The ratio of fixed capital (fixed capital) to the number of firms in the } \\
\text { industry for agricultural products processing industry }\end{array}$ \\
\hline & utfdi & $\begin{array}{c}\text { Total fixed assets } \\
\text { excluding Taiwanese } \\
\text { investment }\end{array}$ & $\begin{array}{c}\text { The total assets of state-owned and non-state-owned industrial } \\
\text { enterprises above designated size minus the amount of Taiwanese } \\
\text { investment in agriculture }\end{array}$ \\
\hline & lab & $\begin{array}{l}\text { Quantity of labor } \\
\text { force }\end{array}$ & $\begin{array}{c}\text { The average number of employees in the segment of the agricultural } \\
\text { products processing industry }\end{array}$ \\
\hline & hum & Human capital & $\begin{array}{l}\text { Agricultural products processing industry breakdown of industrial } \\
\text { enterprises above designated size R \& D number of employees } \\
\text { accounted for the proportion of the number of employees }\end{array}$ \\
\hline & tfdi & $\begin{array}{l}\text { Taiwan direct } \\
\text { investment }\end{array}$ & $\begin{array}{c}\text { Taiwanese Investment in China 's Agricultural Products Processing } \\
\text { Sector }\end{array}$ \\
\hline
\end{tabular}
processing industry in mainland China, $\mathrm{t}$ is time, $\mathrm{mu}$ is individual effect, nu is time fixed effect, and epsilon is residual.

TABLE II. VARIABLE DESIGN AND INTERPRETATION 


\section{B. Data Sources}

This paper chooses 10 sub-sectors of agricultural products processing industry in mainland China, and analyzes panel data from 2007 to 2012. Among them, the investment data of Taiwanese agricultural products processing enterprises from mainland China from the "Taiwan Ministry of Economic Affairs Investment Review Committee"; China's agricultural processing industry 10 sub-sectors sales output and the number of employees are from the "China Statistical Yearbook"; The capital data required for the investment of capital in Taiwan, the export delivery value data required to calculate the trade openness indicators, the fixed capital (original price) data and the industry company data required to calculate the market competition index, and the data of the $\mathrm{R} \& \mathrm{D}$ personnel to calculate the human capital index are derived from the "China Statistical Yearbook"; The calculation of the financial market efficiency indicators of the mainland agricultural products processing industry segmentation industry current liabilities and the total debt data are from the "Almanac of China's Finance"; The data of computing technology level gap between the number of the continent output value and the employees are from the "China statistical yearbook". The data of Taiwan output and the workers are from the meter.

\section{Analysis and Discussion of Empirical Results}

The panel data model includes the mixed effect, the fixed effect and the random effect. The F test and the Hausman test are used to determine the final model, which is the fixed effect model. First, the F test results show that the F value is 254.81 ( $\mathrm{P}$ value is 0 ), which rejects the original hypothesis that all individual dummy variables are 0 and the fixed effect model is better than the mixed effect model; Second, the Hausman test results show that the chi-square value is 77.87 ( $\mathrm{P}$ value is 0 ), which indicates that the fixed effect model is superior to the random effect model. Table 3 shows the results of the fitting of the fixed effect model. It can be seen that the regression coefficient of tfdi is not significant at $95 \%$ confidence level, which indicates that direct investment in Taiwan is not directly related to technology spillover effect on the agricultural products processing industry in mainland China, which may be due to the fact that Taiwanese investment accounted for the proportion of foreign direct investment in China's agricultural products processing industry and the sales output value of Taiwanese investment enterprises accounted for the sales output value of China's agricultural products processing industry were relatively small, the impact of the overall sales of agricultural products processing industry is minimal. Second, the interaction between Taiwanese investment and openness (tfdi $*$ open) and the coefficient of interaction (tfdi*gap) between Taiwanese investment and technical level gap is significant at $99 \%$ confidence level, which indicates that Taiwanese investment can indeed enhance the mainland China's agricultural products processing industry to open up and narrow the cross-strait technology gap, and then bring indirect technical spillover effect on China's agricultural products processing industry. More specifically, Taiwanese investment has directly boosted the export capacity of agricultural products processing industry in mainland China and promoted the development level of agricultural products processing industry by upgrading the new equipment.

TABLE III. FITTING RESULTS OF THE FIXED EFFECT MODEL

\begin{tabular}{|c|c|c|c|c|c|c|}
\hline & Coef. & Std. Err. & $\mathrm{t}$ & $\mathrm{P}>|\mathrm{t}|$ & \multicolumn{2}{|c|}{ [95\% Conf. Interval] } \\
\hline lntfdi & 0.125 & 0.102 & 1.230 & 0.226 & -0.080 & 0.330 \\
\hline lnutfdi & 0.827 & 0.176 & 4.700 & 0.000 & 0.472 & 1.182 \\
\hline lnlabor & 0.218 & 0.283 & 0.770 & 0.445 & -0.353 & 0.788 \\
\hline $\begin{array}{c}\text { Ln(tfdi*hum } \\
\text { ) }\end{array}$ & 0.023 & 0.047 & 0.500 & 0.622 & -0.071 & 0.118 \\
\hline $\ln ($ tfdi*open) & 0.463 & 0.150 & 3.090 & 0.004 & 0.161 & 0.766 \\
\hline $\begin{array}{c}\ln (\text { tfdi*fina) } \\
\ln (\text { tfdi*gap) }\end{array}$ & 0.005 & 0.032 & 0.160 & 0.873 & -0.059 & 0.069 \\
\hline $\ln ($ tfdi*com) & -0.570 & 0.118 & -4.810 & 0.000 & -0.809 & -0.331 \\
\hline _cons & -0.607 & 0.034 & -0.900 & 0.375 & -0.100 & 0.039 \\
\hline sigma_u & 0.698 & 3.318 & -0.180 & 0.856 & -7.303 & 6.090 \\
\hline sigma_e & 0.134 & \multicolumn{7}{|l}{} & & & \\
\hline rho & 0.965 & & & & & \\
\hline
\end{tabular}

\section{CONCLUSION AND SUGGESTIONS}

This paper is based on the panel data of China's agricultural products processing industry in China, the panel data from 2007 to 2012, the direct investment and human capital, trade openness, financial market efficiency, technical level gap and market competition to reflect the indirect technology spillover effect. The results show that Taiwanese direct investment has not been able to bring direct technical spillover effect to the agro-processing industry in mainland China, but it can improve the efficiency of China's agricultural products processing industry by improving the external spillovers of mainland China's agricultural products processing industry and narrow the technical gap between the two sides. And then agricultural products processing industry on the Chinese mainland has an indirect technology spillover effect. The above conclusions show that attracting Taiwanese direct investment is of great strategic significance to the development of agricultural 
products processing industry in mainland China. However, Taiwanese businessmen investment in mainland China's agricultural processing industry has declined at a faster rate in recent years, which deserves the attention of all levels of government and relevant decision-making departments, according to Taiwan's "Ministry of Economic Affairs" Investment Review Committee data.

\section{ACKNOWLEDGMENT}

Author: Chang Lin, female, doctoral student, college of economic, Fujian Agriculture and Forestry University. Email:1jlshlj@163.com.

Corresponding author: Jiangfan Yang, professor, Fujian Agriculture and Forestry University, research direction being for the tea industry economy and management.

\section{REFERENCES}

[1] Yi Kaigang, Taiwan direct investment in mainland China agriculture present situation, problems and Countermeasures of $[\mathrm{J}]$. international trade issues, 2006 (10): 114-115.

[2] Research Center of Transnational Corporations of the Ministry of Commerce of the People's Republic of China .2005 Multinational Corporations Report in China [M]. Beijing: China Economic Publishing House, 2005.

[3] Macdougall D. The benefits and costs of private investment from abroad: a theory approach [J]. Economic Record, 1960, 36 (73): 13-35.

[4] Chen Yanhuang, Zhuang Peifen. Analysis on the Technology Spillover Effect of Taiwan's Agricultural Direct Investment on the Mainland [J]. Taiwan Agricultural Exploration, 2014, (1): 27-28

[5] Crespo N, Fontoura M P. Determinant Factors of FDI Spillovers - What Do We Really Know? [J]. World Development, 2007, 35 (3): 410-425.

[6] Girma S. Absorptive Capacity and Productivity Spillovers from FDI: A Threshold Regression Analysis * [J]. Oxford Bulletin of Economics \& Statistics, 2005, 67 (3): 281-306. 